\title{
VENE ÕPPEKEELEGA PÕHIKOOLI ÕPILASTE JA ÕPETAJATE HOIAKUD EESTIKEELSE AINEÕPPE SUHTES VAHETULT ENNE 2007. AASTA GÜMNAASIUMIREFORMI ALGUST
}

\section{Natalia Vaiss}

\begin{abstract}
Ülevaade. Artiklis uuritakse kvantitatiivselt üheksanda klassi õpilaste ja neid eesti keeles õpetanud pedagoogide hoiakuid osalise eestikeelse aineõppe suhtes ning analüüsitakse, millised tegurid soodustavad õpilaste positiivsete hoiakute kujunemist eesti õppekeele suhtes, pöörates erilist tähelepanu uuringus täheldatud erinevusele osa õppeaineid eesti keeles omandanud ja kõiki õppeaineid vene keeles õppinud põhikoolilõpetajate hoiakute vahel. Artikli lõpuosas vaadeldakse kvalitatiivselt eestikeelse aineõppe positiivseid ja negatiivseid mõjusid, näidatakse probleeme, millega eestikeelses aineõppes osalenud õpilased ja õpetajad on kokku puutunud, ning tutvustatakse nende pakutud võimalikke lahendusi. Analüüs põhineb 2006/2007. õppeaastal läbiviidud kirjalikel küsitlustel vene õppekeelega põhikooli lõpetajate ja eestikeelses aineõppes osalenud õpetajate seas.
\end{abstract}

Võtmesõnad: kakskeelne haridus, üleminek eestikeelsele õppele, teise keele omandamine, eesti keel teise keelena

\section{Sissejuhatus}

Kakskeelset haridust (ingl bilingual education) on määratletud mitmel moel, nii laiemas kui ka kitsamas tähenduses (vt Baker 2006: 213). Klassikalise definitsiooni järgi mõistetakse kakskeelse hariduse all õppetöö sellist korraldust, kus õppekeelena kasutatakse kaht või enamat keelt. Selles tähenduses kasutatakse kakskeelse hariduse mõistet, osutamaks erinevatele kaks- ja mitmekeelsetele õppetöö mudelitele, mis on suunatud nii rahvusvähemustest kui ka -enamustest õpilastele ja mis suuremal või vähemal määral soodustavad õppijate mitmekeelsust. Mõned autorid laiendavad kakskeelse hariduse tüpoloogiat ka õppetöö sellistele korraldustele, mis ei ole oma loomult kakskeelsed ega soodusta õppijate kakskeelsust, kuid mille 
taga on reeglina kindlad sotsiaalsed ja keelepoliitilised eesmärgid, nagu näiteks assimilatsioonile või segregatsioonile suunatud rahvusvähemuslaste õpetamine enamus- või vähemuskeelses koolis (Baker 2006: 215-216, Skutnabb-Kangas, McCarty 2008: 4).

Üheks maailmas levinumaks kakskeelse hariduse mudeliks võib tänapäeval pidada lõimitud aine- ja keeleõppe strateegiat (LAK-õpe; ingl CLIL - Content and Language Integrated Learning). Eesti keeles nimetatakse seda lähenemisviisi keeleõppele sageli ka kakskeelseks (aine)õppeks. Katusmõistena hõlmab LAK-õpe endas kõik kakskeelse hariduse rikastavad, s.o siht- ja emakeele arengut edendavad mudelid. Sellises tähenduses kasutatakse seda terminit ka käesolevas artiklis. Varajane ja hiline keelekümblus, osaline võõrkeelne õpe, mitmesugused keelelaagrid ja -projektid on LAK-õppe tuntumaid vorme. (Hausenberg, Saarso 2008: 17, Mehisto jt 2008: 9)

Eestis on LAK-õppe arengustrateegiad muutunud viimasel aastakümnel aktuaalseks eelkõige seoses vene õppekeelega kooli lõpetajate vähese riigikeele oskuse ja sellest tuleneva üha suureneva vajadusega ühise keeleruumi järele ning 2007. aasta gümnaasiumireformiga.

Vastavalt põhikooli- ja gümnaasiumiseaduse ning põhikooli ja gümnaasiumi riikliku õppekava viimastele muudatustele (PGS 1997, PGS 2000, RÕK 2007) alustasid 2007/2008. õppeaastal kõik vene õppekeelega riigi- ja munitsipaalgümnaasiumid üleminekut osalisele eestikeelsele õppele. Reformi esimesel aastal õppisid 10. klassi õpilased eesti keeles üht eesti kirjanduse kursust (s.t 35 ainetundi). Käesoleval, 2008/2009. õppeaastal peavad 10. klassi astunud gümnasistid lisaks eesti kirjandusele õppima eesti keeles ka kaht ühiskonnaõpetuse kursust või kolme muusikaõpetuse kursust. Järgneval kolmel õppeaastal gümnaasiumisse astujate jaoks lisandub igal aastal veel üks eestikeelne õppeaine, kuni 2011/2012. õppeaastal moodustab eestikeelne õpe vähemalt $60 \%$ gümnaasiumiastme õppemahust. Lisaks eesti kirjandusele, ühiskonna- ja muusikaõpetusele viiakse eesti õppekeelele üle geograafia ja Eesti ajalugu. Reformi peamiseks eesmärgiks on muukeelse gümnaasiumi lõpetajate riigikeele oskuse arendamine, laiendamaks nende edasiõppimisvõimalusi ja konkurentsivõimet tööturul ning soodustamaks integreerumist Eesti ühiskonda.

Juba enne gümnaasiumireformi õpetati paljudes vene õppekeelega koolides mõnd õppeainet eesti keeles, seda nii õpilaste eesti keele oskuse arendamiseks kui ka 2007. aasta ülemineku ettevalmistamiseks. Selline õpetamine ei olnud riiklikult koordineeritud ja koolide lõikes oli olukord väga erinev (vt TNS Emor 2006: 12, Vare 2006: 321). Enamikus koolidest õpetati eesti keeles vaid üksikuid aineid. Mõned koolid (nt Tartu Annelinna Gümnaasium, Tallinna Humanitaargümnaasium) koostasid oma kakskeelse õppekava, mille põhjal on õpilased saanud järkjärgulist eestikeelset aineõpet. Alates 2000. aastast, pärast Keelekümbluskeskuse ametlikku avamist, on paljud koolid liitunud varajase või hilise keelekümbluse programmiga. ${ }^{1}$

Alates gümnaasiumireformi esimesest kavandist (PGS 1993, § 9, § 52) on sellega seotud teemadele pühendatud terve rida uuringuid. Näiteks on uuritud muukeelsete laste kohanemist eesti õppekeelega koolis (Valk 1998, Pavelson, Vihalemm 2002, Rannut 2003 jt), eesti keele õpetamise efektiivsust vene õppekeelega 
koolis (Vare 1999, 2004 jt), keelekümblusmetoodikat (Asser 2003a, Rannut 2001 jt), keelekeskkonna ja õppemudeli mõju muukeelsete õpilaste keeleoskusele ja integratsioonimotivatsioonile (Asser 2001, Rannut 2005). Samuti on analüüsitud vene kooli võimalikke arengumudeleid ja hinnatud koolide valmisolekut gümnaasiumireformiks (Vassiltšenko jt 1998, Läänemets 2002, Asser 2003b, TNS Emor 2004, 2006, Vare 2006 jt). Mõnel määral on juba jõutud jälgida ka vene õppekeelega gümnaasiumide kohustuslikule eestikeelsele õppele ülemineku sujumist (nt Hausenberg, Saarso 2008).

Reformieelsetel aastatel on populaarseks uurimisobjektiks olnud ka kooliuuendustega seotud osapoolte hoiakud. Eesti ühiskonna hoiakuid eelseisva gümnaasiumireformi suhtes on kajastanud Integratsiooni Sihtasutuse tellimusel läbiviidud uuring eestivenelaste keeleoskusest ning eestlaste ja eestivenelaste suhtumisest 2007. aasta reformi (Proos 2005). Uuring näitas, et paar aastat enne gümnaasiumireformi pooldas seda vaid kolmandik eestivenelastest (34\%) ja valdav osa eestlastest (76\%).

Haridus- ja Teadusministeeriumi tellitud uuringud 2004. ja 2006. aastast andsid hea ülevaate eestikeelse aineõppe olukorrast vene koolis ning vene kooli juhtkonna ja õpetajate seisukohtadest osalisele eestikeelsele õppele ülemineku suhtes (TNS Emor 2004, 2006). 2004. aasta uuringu raames viidi läbi ka rühmavestlused kahe Tallinna ja ühe Ida-Virumaa gümnaasiumi õpilastega; 2006. aasta kordusuuringus oli palutud koolijuhtidel ja õpetajatel hinnata õpilaste valmisolekut eesti keeles õppida. Need uuringud näitasid, et kahe aasta jooksul on vene koolide juhtide ja õpetajate hoiakud eestikeelse aineõppe suhtes muutunud tunduvalt positiivsemaks. 2006. aastal toetas üleminekut eestikeelsele aineõppele 94\% küsitletud koolijuhtidest ja 85\% õpetajatest. Seevastu on õpilased ja nende vanemad olnud ja jäänud kõige kriitilisemaks eestikeelse õppe suhtes (TNS Emor 2004: 117, 2006: 29). Üks aasta enne reformi algust oli koolijuhtide hinnangul ligi kaks kolmandikku õpilastest ja lastevanematest huvitatud eestikeelsest aineõppest (TNS Emor 2006: 29).

Siiski polnud enne reformi algust eesti keeles õppima asuvate õpilaste endi suhtumist eestikeelsesse õppesse kvantitatiivselt uuritud, olgugi et asjaosaliste motivatsioon kuulub mitte-emakeelse õppe olulisemate tegurite hulka. Põhjalikult ja pikaajaliselt on Eestis seni uuritud vaid keelekümblusprogrammis osalenud õpilaste toimetulekut eri õppeainetes ja nende hoiakuid programmi suhtes (Asser jt 2005). Eesti keeles üksikuid aineid õppinud õpilaste arvamused on jäänud veel kajastamata.

Käesolev artikkel tutvustab kvantitatiivseid ja kvalitatiivseid meetodeid kombineerivat hoiakute uuringut, mille artikli autor kavandas ja teostas Jyväskylä ülikooli doktorantuuris õppimise raames. Uuringut aitas läbi viia sihtasutuse Archimedes doktoriõppe toetus. Uuringul oli neli põhieesmärki:

1) uurida vene õppekeelega põhikooli lõpetajate suhtumist eestikeelsesse aineõppesse vahetult enne gümnaasiumireformi algust;

2) selgitada õpilaste eestikeelsesse aineõppesse suhtumist mõjutavaid tegureid;

3) selgitada põhjusi, mis määravad põhikooli õpilaste ja eestikeelses aineõppes osalenud õpetajate hinnangu 2007. aasta gümnaasiumireformi vajalikkuse kohta;

4) analüüsida eestikeelses aineõppes osalenud õpilaste ja õpetajate kogemusi mitte-emakeelsest aineõppest. 


\section{Andmekogumismeetod ja respondendid}

Tutvustatavad uurimistulemused põhinevad detsembrist 2006 maini 2007 läbiviidud internetiküsitlustel vene õppekeelega põhikooli lõpetajate ja eesti keeles õpetavate pedagoogide seas. Elektroonilised ankeedid koosnesid nii valikvastusega kui ka avatud küsimustest, mis võimaldas saada nii kvantitatiivseid kui ka kvalitatiivseid andmeid.

Uuringus osalesid 24 kooli õpilased Eesti kolmest sotsiolingvistiliselt erinevast piirkonnast: Harjumaa, Ida-Virumaa ja muu Eesti. Uuringu hüpoteesi järgi võisid eestlaste ja mitte-eestlaste osakaalul ja eestikeelse õppe levikul põhinevad regionaalsed erinevused mõjutada olulisel määral õpilaste seisukohti.

Koolide regionaalselt stratifitseeritud valim moodustati lihtsa juhusliku valiku abil. Uuringus osalesid valimisse sattunud ja uuringust osa võtma nõustunud koolide kõik vene või eesti-vene õppekeelega üheksandad klassid. Juhul, kui väljavalitud koolis õpetati eesti keeles mõningaid põhikooli ainetest, paluti uuringus osaleda ka kõigil 5.-9. klassis eesti keeles õpetavatel pedagoogidel.

Enne küsimustiku täitmist tutvustati respondentidele uuringu eesmärke, gümnaasiumireformiga seotud muudatusi ning küsimustiku täitmise reegleid. Õpilaste ankeedid olid venekeelsed, õpetajatel oli võimalik valida eesti- ja venekeelse variandi vahel. Enamik õpilasi vastas küsimustikule ootuspäraselt vene keeles, üksikud õpilased siiski ka eesti keeles. Enamik vene emakeelega õpetajatest eelistas vastata eesti keeles.

Kokku võttis uuringust osa 30 eestikeelse LAK-õppe õpetajat ja 815 vene või eesti-vene õppekeelega üheksanda klassi õpilast, mis on veidi üle $20 \%$ kõikidest õpilastest, kes õppisid 2006/2007. õppeaastal üheksandas klassis kõiki või osa aineid vene keeles. Vastavalt tolleaegsele regiooniti jagunemisele ${ }^{2}$ moodustasid lõppvalimi 400 õpilast Harjumaalt (49\%), 315 õpilast Ida-Virumaalt (39\%) ja 100 oppilast Eesti teistest maakondadest (12\%).

Selleks, et tagada õpilaste lõppvalimi statistiline representatiivsus eestikeelse aineõppe kogemuse suhtes, kallutati valim vastavusse eestikeelses aineõppes osalenud põhikoolilõpetajate osakaaluga kõigis kolmes sotsiolingvistilises piirkonnas ${ }^{3}$. Kokku on valimis esindatud 279 eestikeelses aineõppes osalenud õpilast ja 536 õpilast, kes olid õppinud põhikooli vältel üksnes vene keeles (välja arvatud eesti keele tunnid).

Enamik uuringust osa võtnud õpilasi (97\%) oli vanuses 15-16 eluaastat. Üksikud respondendid olid 14- või 17-aastased. Enamikul (99\%) oli emakeeleks vene keel, veel nimetati emakeelena ukraina, läti, aserbaidžaani ja gruusia keelt.

Uuringus osalenud LAK-õppe õpilased omasid väga erinevat eestikeelse aineõppe kogemust. Umbes pooled neist $(n=139)$ olid õppinud põhikooli jooksul vaid üht või kaht ainet eesti keeles ning pooled $(n=140)$ üht või mitut õppeainet igal õppeaastal. Viimaste hulgas olid ka 44 hilises keelekümblusprogrammis osalenud õpilast, kes õppisid vähemalt 50\% ainetest eesti keeles.

LAK-õppe õpetajatele mõeldud küsimustikule vastasid 13 kooli pedagoogid, kelle hulgas oli 13 õpetajat Harjumaalt, 7 Ida-Virumaalt ja 10 teistest maakondadest. 12 õpetajat märkis oma emakeeleks eesti keele ja 17 vene keele; ühel respondendil

2 Haridus- ja Teadusministeeriumi statistikaandmete kohaselt (EHIS, 11.10.2006) õppis Eestis 2006/2007. öppeaastal vene või eesti-vene õppekeelega üheksandas klassis 3917 õpilast, nende hulgas Harjumaal 1921 (49\%), Ida-Virumaal $1515(39 \%)$ ja ülejäänud Eestis 481 (12\%).

3 Üldkogumi moodustavate koolide täiendavast telefoniküsitlusest saadud andmete põhjal õppis põhikooli vältel vähemalt üht ainet eesti keeles 34\% 2006/2007. õppeaastal vene või eesti-vene õppekeelega üheksanda klassi lõpetajatest. Harjumaal oli selliseid õpilasi $36 \%$, Ida-Virumaal $26 \%$ ja ülejäänud Eestis $53 \%$. 
olid mõlemad keeled (nii eesti kui vene keel) kasutusel emakeelena. Kõik vastajad peale ühe olid naisõpetajad. Kõige noorem vastanutest oli 26-aastane ja vanim 59-aastane. Nende tööstaaž ulatus kahest 38 aastani, eesti keeles õpetamise kogemus ühest üheksa aastani, jäädes enamikul alla kolme aasta.

Suurema osa pedagoogidest moodustasid eesti keele õpetajad (12) ja klassiõpetajad (5). Loodus- ja reaalainete õpetajatest oli respondentide seas neli füüsika- ja matemaatikaõpetajat, kaks keemia- ja bioloogiaõpetajat ja üks informaatikaõpetaja. Humanitaarainete õpetajatest osales uuringus kaks ajalooõpetajat ning loov- ja oskusainete õpetajatest kaks kehalise kasvatuse õpetajat, muusika ja tööõpetuse õpetaja. Respondendid õpetasid eesti keeles valdavalt nende erialale vastavaid aineid. Eesti keele õpetajad õpetasid lisaks keeletundidele põhiliselt eesti kirjandust ning erinevaid loodus-, oskus- ja loovaineid. Neljal eesti keele õpetajal oli ülikoolis omandatud lisaeriala kirjanduses, ajaloos, muusikas või tööõpetuses. Ülejäänud juhtudel on keeleõpetajad kas läbinud erialase täiendkoolituse või on saanud LAK-õppe pedagoogideks tänu oma heale eesti keele oskusele.

\section{Põhikoolilõpetajate hoiakud eestikeelse aineõppe suhtes}

Õpilaste hoiakuid eestikeelse aineõppe suhtes uuriti mitmete küsimuste abil. Olulisemad neist on "Kas sa pead 2007. aasta gümnaasiumireformi vajalikuks?", "Kas sinu arvates peaksid gümnaasiumiõpilased õppima vähemalt mõningaid aineid eesti keeles?", "Millise eesti- või võõrkeelse õppemahuga gümnaasiumis sa eelistaksid oma õpinguid jätkata?” ning "Kui sa oleksid võinud valida, mis keeles sa tahaksid õppida suuremat osa (üle 60\%) aineid gümnaasiumis?”. Vastused nendele küsimustele aitasid hinnata õpilaste üldisemat psühholoogilist valmidust eesti keeles õppida, nende hoiakuid gümnaasiumireformi suhtes ning eelistusi põhilise õppekeele valikul. Lisaks esitati respondentidele nende keeleoskust, tulevikuplaane, vanemate hoiakuid gümnaasiumireformi suhtes ja muud taustinformatsiooni puudutavaid küsimusi selgitamaks, millised tegurid soodustavad õpilaste positiivsete hoiakute kujunemist eestikeelse aineõppe suhtes.

Ilmnes, et põhikoolilõpetajate hoiakud gümnaasiumireformi suhtes sõltusid suurel määral sellest, kuidas suhtusid sellesse õpilaste endi hinnangul nende vanemad $(r=0,6, p<0,01)$. Vanemate arvatav suhtumine reformi korreleerus ka õpilaste üldise motivatsiooniga eesti keeles õppida $(\mathrm{r}=0,4, \mathrm{p}<0,01)$. Lisaks olid mõnevõrra positiivsemad hoiakud reformi ja eestikeelse õppe suhtes õpilastel, kes seostasid oma tulevikku Eestiga, ning neil, kes kavatsesid jätkata õpinguid kõrgkoolis (mõlemal juhul $r=0,1, p<0,01$ ). Soov jätkata õpinguid gümnaasiumis ei osutanud uuringu andmete põhjal statistiliselt olulist mõju õpilaste hoiakutele.

Nii reformi kui ka üldisemalt eestikeelse aineõppe suhtes olid positiivsemalt häälestatud ka need õpilased, kes hindasid oma eesti keele oskust väga heaks või heaks $(\mathrm{r}=0,2, \mathrm{p}<0,01)$, ning need, kes arvasid, et nende keeleoskus on piisav eesti keeles õppimiseks $(r=0,3, p<0,01)$. Kõrgemad hinnangud oma eesti keele oskusele olid omakorda tingitud eelnevast kogemusest eestikeelses aineõppes (tabel 1). Samuti leidsid LAK-õppes osalenud õpilased mõnevõrra sagedamini, et nad on andekad või üsna andekad keelte õppimisel. Sarnaste tulemusteni on jõutud ka mitmetes varasemates uuringutes (Asser 2001: 13, Cummins, Swain 1986: 98). 
Tabel 1. LAK-õppes osalenud ja mitteosalenud õpilaste hinnangud oma eesti keele oskusele ja keeleandekusele (\%)

\begin{tabular}{|l|c|c|c|c|c|}
\hline Hinnang & $\begin{array}{c}\text { LAK-õppes } \\
\text { osalenud } \\
\text { ópilased }\end{array}$ & $\begin{array}{c}\text { LAK-õppes } \\
\text { mitteosalenud } \\
\text { ópilased }\end{array}$ & $\begin{array}{c}\text { Vahe LAK-õppes } \\
\text { osalenud õpilaste } \\
\text { kasuks }\end{array}$ & r & $\begin{array}{c}\text { Kõik } \\
\text { ópilased }\end{array}$ \\
\hline $\begin{array}{l}\text { Hindab oma eesti keele } \\
\text { oskust väga heaks või } \\
\text { heaks }\end{array}$ & $47 \%$ & $29 \%$ & +18 & $0,2^{* *}$ & $35 \%$ \\
\hline $\begin{array}{l}\text { Hindab oma keele- } \\
\text { oskust piisavaks eesti } \\
\text { keeles õppimiseks }\end{array}$ & $47 \%$ & $18 \%$ & +29 & $0,4^{* *}$ & $28 \%$ \\
\hline $\begin{array}{l}\text { Peab ennast andekaks } \\
\text { või üsna andekaks } \\
\text { keelte õppimisel }\end{array}$ & $76 \%$ & $64 \%$ & +12 & $0,1^{* *}$ & $69 \%$ \\
\hline
\end{tabular}

$r=$ Pearsoni korrelatsioonikordaja

** seos on statistiliselt oluline olulisustõenäosusega (p) alla 0,01

Nii LAK-õppes osalenud kui ka kõiki aineid vene keeles õppinud põhikoolilõpetajate suhtumine eestikeelsesse õppesse sõltus märkimisväärselt ka eesti keeles oppitavate ainete üldmahust. Õpilaste suhtumine eestikeelsesse õppesse muutus tunduvalt negatiivsemaks, kui eesti keeles õpitavate ainete maht lähenes poolele gümnaasiumi õppekavast või ületas selle (tabel 2). Näiteks oli õpilaste valmisolek õppida mõningaid aineid eesti keeles vähemalt kaks korda suurem soovist õppida $50 \%$ ainetest riigikeeles. Samuti oli ka respondentide suhtumine üleminekusse eestikeelsele õppele tunduvalt kriitilisem võrreldes nende valmisolekuga üksikuid aineid eesti keeles õppida. Vaid 19\% põhikoolilõpetajatest (sealhulgas 15\% LAKõppes mitteosalenud ja $25 \%$ osalenud õpilastest) arvas, et reform on vajalik kavandatavas 6o-protsendilises eestikeelse õppe mahus. Samas oli üle poole (56\%) neist (sealhulgas 49\% LAK-õppes mitteosalenud ja 68\% osalenud õpilastest) nõus sellega, et gümnaasiumis võiks õppida vähemalt mõningaid aineid eesti keeles.

Tabel 2. LAK-õppes osalenud ja mitteosalenud õpilaste hoiakud eestikeelse aineõppe suhtes (\%)

\begin{tabular}{|l|c|c|c|c|c|}
\hline Hoiak & $\begin{array}{c}\text { LAK-õppes } \\
\text { osalenud } \\
\text { ópilased }\end{array}$ & $\begin{array}{c}\text { LAK-õppes } \\
\text { mitteosalenud } \\
\text { ópilased }\end{array}$ & $\begin{array}{c}\text { Vahe LAK-õppes } \\
\text { osalenud õpilaste } \\
\text { kasuks }\end{array}$ & r & $\begin{array}{c}\text { Kõik } \\
\text { õpilased }\end{array}$ \\
\hline $\begin{array}{l}\text { Arvab, et vene õppe- } \\
\text { keelega gümnaasiumi } \\
\text { öpilased peavad õppima } \\
\text { vähemalt mõningaid } \\
\text { aineid eesti keeles }\end{array}$ & $68 \%$ & $49 \%$ & +19 & $0,2^{* *}$ & $56 \%$ \\
\hline $\begin{array}{l}\text { Soovib õppida gümna- } \\
\text { siumis, kus umbes 50\% } \\
\text { ainetest õpetatakse eesti } \\
\text { keeles }\end{array}$ & $30 \%$ & $16 \%$ & +14 & $0,2^{* *}$ & $21 \%$ \\
\hline $\begin{array}{l}\text { Arvab, et 2007. aasta } \\
\text { gümnaasiumireform (mil- } \\
\text { le tulemusena õpetatakse } \\
\begin{array}{l}60 \% \text { ainetest eesti keeles) } \\
\text { on vajalik }\end{array}\end{array} \quad 25 \%$ & $15 \%$ & +10 & $0,2^{* *}$ & $19 \%$ \\
\hline $\begin{array}{l}\text { Soovib õppida üle 60\% } \\
\text { gümnaasiumiastme } \\
\text { ainetest eesti keeles }\end{array}$ & $14 \%$ & $5 \%$ & +9 & $0,1^{* *}$ & $8 \%$ \\
\hline
\end{tabular}

$r=$ Pearsoni korrelatsioonikordaja

** seos on statistiliselt oluline olulisustõenäosusega (p) alla 0,01 
Piirkondade lõikes erinesid Harjumaa ja Ida-Virumaa õpilased oma tunduvalt kriitilisemate hoiakutega Eesti teiste maakondade põhikoolilõpetajatest kõigi küsimuste puhul (tabel 3).

Tabel 3. Õpilaste hoiakud eestikeelse aineõppe suhtes regioonide lõikes (\%)

\begin{tabular}{|l|c|c|c|c|}
\hline Hoiak & $\begin{array}{c}\text { Harjumaa } \\
\text { õpilased }\end{array}$ & $\begin{array}{c}\text { Ida-Virumaa } \\
\text { õpilased }\end{array}$ & $\begin{array}{c}\text { Ülejäänud Eesti } \\
\text { õpilased }\end{array}$ & $\begin{array}{c}\text { Kõik } \\
\text { ópilased }\end{array}$ \\
\hline $\begin{array}{l}\text { Arvab, et vene õppekeelega } \\
\text { gümnaasiumi õpilased peavad } \\
\begin{array}{l}\text { öppima vähemalt mõningaid } \\
\text { aineid eesti keeles }\end{array}\end{array}$ & $55 \%$ & $50 \%$ & $76 \%$ & $56 \%$ \\
\hline $\begin{array}{l}\text { Soovib õppida gümnaasiumis, } \\
\text { kus umbes 50\% ainetest õpeta- } \\
\text { takse eesti keeles }\end{array}$ & $17 \%$ & $20 \%$ & $40 \%$ & $21 \%$ \\
\hline $\begin{array}{l}\text { Arvab, et 2007. aasta gümnaa- } \\
\text { siumireform on vajalik }\end{array}$ & $18 \%$ & $17 \%$ & $27 \%$ & $19 \%$ \\
\hline $\begin{array}{l}\text { Soovib õppida üle 60\% } \\
\text { gümnaasiumiastme ainetest } \\
\text { eesti keeles }\end{array}$ & $6 \%$ & $8 \%$ & $19 \%$ & $8 \%$ \\
\hline
\end{tabular}

Õpilaste hoiakuid gümnaasiumireformi suhtes aitasid sügavamalt mõista nende vastused täiendavatele avatud küsimustele. Viimastele vastas üle $70 \%$ respondentidest. Uuringu kvalitatiivsete andmete põhjal võiks teha järelduse, et kriitiline suhtumine reformi oli sageli tingitud hirmust haridussüsteemi põhjalike muutuste ees. Samas tajusid paljud, sealhulgas ka eestikeelset õpet pooldavad noored, et reform seab ohtu venekeelse gümnaasiumihariduse.

Gümnaasiumireformi toetavad õpilased põhjendasid oma seisukohta enamasti selliste väidetega nagu "Me elame Eestimaal ja peame oskama riigikeelt", "Kõik Eesti elanikud peavad valdama riigikeelt”, "Eesti keel on Eestis väga vajalik” jms (vt ka TNS Emor 2004: 96). Võiks järeldada, et ühelt poolt peegeldavad sellised seisukohad teadvustatud vajadust osata riigikeelt ning arusaama, et eestikeelne õpe aitab tõhusamalt arendada eesti keele oskust, teiselt poolt aga isiklikku seotust Eesti riigiga.

Siiski olid enamikul reformi pooldavatest õpilastest pigem instrumentaalsed kui integratiivsed motiivid oma keeleoskuse arendamiseks. Enamik neist vastas, et parem eesti keele oskus "aitab neid tulevikus" kõrgkooli sisseastumisel ja seal õppimisel ning hea töökoha leidmisel tänu omandatud kõrgharidusele. Vaid mõned õpilastest (valdavalt LAK-õppe õpilased Harjumaalt ja Ida-Virumaalt) mainisid oma vastustes, et eestikeelne aineõpe annab neile (lisa)võimalused keelepraktikaks ning hõlbustab seega suhtlemist eestlastega. Üksikutel juhtudel vastati, et reform aitab Eesti ühiskonna integratsioonile kaasa ning et eestikeelne õpe võib arendada mõtlemisprotsesse ja soodustada kakskeelsust.

Ülemineku vastu olevad õpilased tõid oma vastuseisu põhjendamiseks esile väga erinevaid seisukohti. Allpool on välja toodud kõige tüüpilisemad väited. ${ }^{4}$

(1) See muudab veelgi raskemaks niigi pingelise õppimise gümnaasiumis.

(2) Kes tahtis, see sai eesti keele selgeks ka ilma reformita, las siis jääb kõik endist viisi.

4 Artiklis toodud õpilaste väited on tõlkinud eesti keelde artikli autor. 
（3）Kõik õpilased ei saa vähese keeleoskuse tõttu tulla toime eestikeelse aineõppega.

(4) Head haridust võib saada ainult emakeeles õppides.

(5) Vene kooli õpilaste teadmiste tase jääb madalamaks võrreldes eesti kooli õpilastega; siis on juba mõttekam eesti kooli minna.

(6) Paljud sooviksid pärast gümnaasiumi lõpetamist välismaale õppima minna ning kui neil on tunnistusel halvad hinded, ei saa nad enam seda teha.

(7) Kõik ei soovi ju eesti keeles õppida. Samas neile, kes ei kavatse Eestisse jääda, pole see üldse vajalik.

(8) Ma arvan, et venekeelsed koolid peaksid ka jääma.

(9) Igal inimesel peab olema valikuvabadus.

Leidus ka üsnagi agressiivseid mõtteavaldusi ning meie-nemad-vastandamisi. Näiteks nähti reformis "tahet venelastest vägisi eestlasi teha", "tahet hävitada venekeelset haridust Eestis" jms. Sageli ei oldud nõus ka sellega, et eestikeelne aineõpe algab alles gümnaasiumis (vt ka TNS Emor 2004: 104). Õpilaste arvamuste kohaselt peaks eestikeelsele õppele üleminek algama juba alg-või põhikoolis. Seevastu gümnaasiumis sooviksid õpilased pöörata rohkemat tähelepanu emakeelele ning õppida eesti keeles nende enda sõnastuses “mitte rohkem kui 50\% õppeainetest”. Mõned respondendid pakkusid ka omapoolseid alternatiive kohustuslikule reformile.

(10) Oleks parem, kui eksisteeriksid nii keelekümblusgümnaasiumid kui ka tavalised venekeelsed gümnaasiumid, kus need, kellel on tahtmist, saaksid õppida mõningaid aineid eesti keeles.

(11) Mulle ei meeldi, et kõik peavad õppima valdavalt humanitaaraineid eesti keeles. Paljudel oleks vaja matemaatikat või bioloogiat kõrgkooli sisseastumisel. Ma arvan, et oleks parem, kui õpilased saaksid ise valida, kui palju ja milliseid aineid nad tahavad eesti keeles õppida. Kui vene kooli ei saa leida kõikide ainete õpetajaid, siis võiks ju käia eesti koolis seda ainet õppimas. Nii suhtleks ka eestlastega rohkem.

Niisiis oleksid vähemalt pooled küsitletud põhikoolilõpetajatest huvitatud üksikute ainete õppimisest eesti keeles. Samas eelistas enamik neist õppida suuremat osa gümnaasiumiainetest endiselt vene keeles.

\section{LAK-õppe pedagoogide hoiakud eestikeelsele ôppele ülemineku suhtes}

Nagu põhikooli lõpetajadki, olid küsitletud LAK-õppe õpetajad küllaltki kriitilised gümnaasiumireformi suhtes. Vaid alla poole neist (12 õpetajat 30-st) arvas, et reform on sätestatud kujul vajalik.

Kuigi uuringus osalenud õpetajate arv oli väga väike, võib siiski välja tuua, et eesti emakeelega LAK-õppe õpetajad suhtusid reformi tunduvalt soosivamalt kui nende vene emakeelega kolleegid. Reformi toetas 17 vene emakeelega õpetajast 
neli ning 12 eesti emakeelega õpetajast kaheksa. Uuringust osavõtnud kakskeelne pedagoog ei osanud ülemineku vajalikkuse suhtes kindlat seisukohta võtta.

Regionaalses lõikes olid kõige skeptilisemad Ida-Virumaa õpetajad (kokku 7), kellest toetas reformi kaks õpetajat. Harjumaa õpetajatest (kokku 13) pooldas reformi elluviimist kuus ning teiste maakondade pedagoogidest (kokku 10) neli õpetajat. Täheldatud rahvuslikud ja regionaalsed erinevused on kooskõlas varasemate uuringute tulemustega (Proos 2005: 30, TNS Emor 2006: 7).

Erialade lõikes suhtusid üleminekusse kõige positiivsemalt eesti keele ja humanitaarainete õpetajad. Reformi toetasid mõlemad uuringust osavõtnud ajalooõpetajad ja 12 keeleõpetajast seitse. Kõige kriitilisemalt olid meelestatud loodus- ja reaalainete õpetajad (kokku 7) - nende hulgas polnud ühtegi reformi toetavat õpetajat. Neljast oskus- ja loovainete õpetajast pooldas reformi üks ning viiest klassiõpetajast kaks.

Mõnevõrra positiivsemad ülemineku suhtes olid need õpetajad, kellel on eestikeelse aineõppe kogemust üle kolme aasta. Reeglina jäid sellesse kategooriasse õpetajad vanuses $36-50$ aastat.

Nagu õpilasedki, arvasid ka reformi toetavad õpetajad, et osa õppeainete õppimine eesti keeles aitab tulevastel gümnaasiumilõpetajatel paremini omandada riigikeelt, hõlbustab kõrghariduse saamist ning tõstab nende konkurentsivõimet tööturul. Üksikud respondendid mainisid, et gümnaasiumireform soodustab integratsiooniprotsesse. Paljud olid arvamusel, et reform peab algama gümnaasiumist varasemates kooliastmetes.

(12) See on ainus võimalus, et noored omandaksid riigikeele ja integreeruksid Eesti ühiskonda.

(13) Muukeelsel õpilasel on endal hiljem kergem saada Eestis head haridust.

(14) See oleks pidanud toimuma tasapisi ja varem, nüüd on viimane aeg, kuna see on minu meelest kindlaim võimalus, et noored omandavad keele paremal tasemel kui siiani. Arvan, et reform peab algama juba altpoolt, et oleks olemas baas, kui jõutakse gümnaasiumi (õpilastel on raskeid ja uusi aineid kergem õppida, kui põhikoolis on omandatud parem keeleoskus).

Reformi vastu olevad õpetajad arvasid seevastu, et planeeritud muudatused ei aita gümnaasiumilõpetajatel eesti keelt omandada tasemel, mis oleks piisav nende konkurentsivõime tõstmiseks.

(15) Minu meelest ei tõsta see venekeelsete õpilaste konkurentsivõimet, vaid ainult halvendab olukorda.

(16) Kui on üks ainetund nädalas, siis selle aine õpetamine eesti keeles ei anna midagi .. Terake siit ja sealt kaob ära ja tulemust ei anna.

Samuti rõhutati, et tähtis on õpilaste enda soov eesti keeles õppida.

(17) Ma arvan, et olemasolev keelekümblusprogramm annab võimaluse nendele, kes on asjast huvitatud. Kohustuslikku reformi ei poolda.

Paljud olid seisukohal, et reformi elluviimiseks ei ole veel piisavalt ettevalmistusi tehtud. 
(18) On veel vara eesti keelele üle minna. Kõigis koolides ei ole piisaval hulgal spetsialiste ja ka spetsialistidel on vaja aega kohanemiseks. Esineb probleeme õppematerjalide, töövihikute ja lihtsalt eesti keelde suhtumisega.

LAK-õppe õpetajate skeptilise suhtumise on tõenäoliselt kujundanud kokkupuude mitte-emakeeles õppimise ja õpetamisega kaasnevate probleemidega.

\section{Eestikeelse aineõppe positiivsed ja negatiivsed mõjud}

Uuringus osalenud 279 eestikeelset õpet kogenud õpilasest 109 ehk umbes $40 \%$ avaldas arvamust, et neile väga või suurel määral meeldib õppida eesti keeles. Umbes sama paljud väitsid, et neile eestikeelne aineõpe eriti ei meeldi, ja 18\% kinnitas, et ei meeldi üldse.

Vastates küsimusele “Mis sulle meeldib eesti keeles õppimise juures?”, mainisid LAK-õppe õpilased põhiliselt eesti keele oskuse efektiivsemat arenemist. Erinevalt gümnaasiumireformi pooldamise põhjustest, kus esikohal olid instrumentaalsed motiivid, domineeris siin integratiivne motivatsioon. Paljud rõhutasid, et eestikeelse aineõppe tulemusena hakkasid nad paremini eestikeelsest kõnest aru saama ja õppisid oma mõtteid ladusamalt väljendama, mis võimaldab neil enesekindlamalt suhelda eesti keeles nii teenindusasutustes kui ka sõprade ja tuttavatega. Mõnedes vastustes leiti ka, et tänu eestikeelsele aineõppele on edaspidi lihtsam õppida gümnaasiumis ja kõrgkoolis; et eestikeelne õpe soodustab kakskeelsuse arenemist ja toob kaasa "topeltkasu" - võimaldab õppida nii ainet kui ka eesti keelt. Oli ka positiivseid hinnanguid põhjustel, et õpilastele meeldib eesti keel, õpetajad, keelekümblusprogramm või et "eesti keeles on huvitavam õppida".

Peamiseks eestikeelse õppe negatiivseks küljeks nimetasid LAK-õppes osalenud õpilased asjaolu, et võrreldes emakeelse õppega muutus õppimine raskemaks, sest lisaks aine omandamisele peavad nad meelde jätma palju eestikeelseid termineid ja kulutama palju aega tõlkimisele. Sageli mainiti ka teisi ebapiisava keeleoskusega seonduvaid raskusi (ei saa aru õpiku materjalist ja õpetaja seletustest; ei oska vastata küsimustele, sest ei suuda formuleerida oma mõtteid korrektselt; raske on kirjutada kirjandeid ja kontrolltöid, teha koduseid ülesandeid jms). Mõnikord rõhutati, et aineteadmised ja emakeele oskused jäid veidi nõrgemaks ning hinded on läinud halvemaks. Sarnaseid probleeme on täheldatud ka keelekümblusõpilaste puhul (vt Cummins, Swain 1986: 17, Asser jt 2005: 61-62).

Küsitluses osalenud LAK-õppe õpetajad olid samuti arvamusel, et eesti keeles kui mitte-emakeeles õppimise põhiliseks probleemiks on keelelised raskused ning sellega kaasnev lisakoormus. Õpilastest sagedamini rõhutasid õpetajad kõrvalise abi vajadust koduste ülesannete tegemisel, ainealaste teadmiste lünklikkust ja raskusi mõtete korrektsel väljendamisel emakeeleski. Oluliseks probleemiks pidasid õpetajad ka keeleliselt kohandatud õppematerjalide puudumist.

Üksikud LAK-õppes osalenud õpilased ja mõned nende õpetajatest tõdesid, et ebapiisava keeleoskuse tõttu võivad tekkida psühholoogilised barjäärid, langeda õpimotivatsioon ja enesekindlustunne.

(19) Mulle tundub, et vene keeles omandan teadmisi kiiremini ja ilma pingutusteta, aga eesti keeles suudan palju vähem kui vene keeles .. Vahel tekib abituse ja alaväärsuse tunne. 
(20) .. Vähese keeleoskusega õpilased püüavad tunnis märkamatuks jääda. Sageli loobuvad nad isegi vastamast, sest nad kardavad öelda midagi valesti

Sageli ei meeldinud õpilastele, et nende õpetajad ei oska tõlkida termineid või raskeid sõnu vene keelde, annavad palju kirjalikke ülesandeid, jagavad tunnis vähe selgitusi, räägivad liiga kiiresti ja kasutavad oma kõnes liiga raskeid väljendeid ning "püüavad õpetada pigem keelt kui õppeainet”.

Eelkirjeldatud probleemide leevendusena nägid LAK-õpet kogenud õpilased seda, et õpetajad ei oleks väga ranged hindamisel, arvestaksid õpilaste individuaalseid võimeid, annaksid vähem kirjalikke ja koduseid ülesandeid ning tunni lõpus esitaksid kokkuvõtte kõige vajalikumast. Paljud sooviksid, et õpetajad tõlgiksid rasket informatsiooni vene keelde ja lubaksid vajadusel vastata vene keeles. Sarnaseid tulemusi on saadud ka Eesti keelekümblusõpilaste uuringus (Asser jt 2005: 62).

LAK-õppe pedagoogid arvasid, et probleemi lahendamiseks peab eelkõige tõhustama eesti keele õpet kõikides kooliastmetes, looma rohkem võimalusi kooliväliseks keelepraktikaks ja alustama ettevalmistust üleminekuks juba algkoolist alates. Samuti pidasid õpetajad oluliseks vene koolidele mõeldud eestikeelsete ôppematerjalide loomist ja laste õpimotivatsiooni tõstmist.

Eestikeelse aineõppe põhiliseks raskuseks nimetasid õpetajad suuremat ajakulu tunni ettevalmistamisel, mis on tingitud vajadusest leida sobivat õppematerjali ja kohandada seda laste vajadustele (vt ka TNS Emor 2006: 35, 46, 79). Sealjuures rõhutasid vene emakeelega pedagoogid, et neil ei tule mitte ainult leida laste keeleoskusele vastavat õppematerjali, vaid ka "valmistada oma tund keeleliselt ette". Samuti tekitas õpetajatele muret "osa õpilaste vastumeelsus eesti keeles õppida" ning "lapsevanemate ja kolleegide poolse toetuse puudumine" (vt ka Hausenberg, Saarso 2008: 22). Vene emakeelega õpetajad muretsesid tihti oma hääldamise ja ebatäiusliku keeleoskuse pärast. Eesti emakeelega õpetajatel esines probleeme distsipliiniga vene ja eesti laste temperamendi erinevuse tõttu. Paljud mainisid, et vajaksid suuremat eesti keeles õpetamise kogemust, selleks et lisaks põhjalikele ainealastele teadmistele arendada edukalt ka keeleoskust.

Kui õpetajatel paluti nimetada mitte-emakeelse õpetamisega kaasnevaid positiivseid momente, vastas enamik LAK-õppe pedagooge, et rahuldust toovad neile opilaste head tulemused, seda nii aine kui ka keele omandamisel. Samuti tunnevad nad rõõmu, nähes õpilaste huvi aine ja eesti keele vastu ning saades positiivset tagasisidet õpilastelt ja nende vanematelt. Paljud õpetajad rõhutasid, et eesti keeles õpetamine annab neile häid võimalusi erialaseks enesearendamiseks (vt ka TNS Emor 2006: 35). Vene emakeelega õpetajad nägid eestikeelses aineõppes lisaks ka suurepärast võimalust igapäevaseks keelepraktikaks ja oma eesti keele oskuse arendamiseks.

Niisiis rõõmustavad eestikeelses aineõppes osalevad õpetajad ja õpilased, nagu ka nende emakeeles õppivad ja õpetavad kaaslased, eelkõige saavutatud tulemuste üle. Mitte-emakeelse aineõppe vaieldamatuks eeliseks emakeelse aineõppe ees on võimalus omandada mitte ainult head ainealased teadmised, vaid ka märgatavalt parem teise keele oskus. Samas on mainitud lisaväärtusel ka oma hind: tuleb ületada keelelised raskused ja psühholoogilised barjäärid ning teha rohkem jõupingutusi selleks, et saavutada püstitatud eesmärgid. 


\section{Kokkuvõte}

Uuringu tulemused näitasid, et valdav osa vene õppekeelega põhikooli lõpetajatest oli vahetult enne gümnaasiumireformi algust teadvustanud eestikeelse aineõppe praktilist ehk instrumentaalset vajadust, kuid siiski ei soovinud enamik neist õppida suuremat osa gümnaasiumiainetest eesti keeles.

Vaatamata sellele, et eestikeelses aineõppes osalenud õpilaste hoiakud mitteemakeelse aineõppe suhtes olid märgatavalt positiivsemad kui nende tavalise ainekava järgi õppinud kaaslaste seisukohad, leidus ikkagi ka nende hulgas kakskeelse haridusmudeli vajalikkuses ja tulemuslikkuses kahtlejaid. Mõned uuringus osalenud LAK-õppe õpetajad olid samuti küllaltki skeptilised kohustusliku gümnaasiumireformi suhtes.

Õpilaste kartused olid sageli tingitud hirmust harjumuspärase haridussüsteemi põhjalike muutuste ees, olles tihedalt seotud nende vanemate suhtumisega eestikeelsesse õppesse. Eestikeelses aineõppes osalenud õpetajad olid sageli kriitilised reformi ettevalmistuse taseme suhtes ning kahtlesid selles, kas üleminek osalisele eestikeelsele õppele aitab kõigil õpilastel omandada tunduvalt parema riigikeele oskuse.

Eestikeelset aineõpet kogenud õpilaste raskused olid enamasti seotud nende ebapiisava keeleoskusega. Seega on paljud eesti õppekeelele gümnaasiumiastmes ülemineku probleemid lahendatavad õpilaste parema keelelise ettevalmistusega põhikoolis.

Vene koolis eesti keeles õpetavad pedagoogid vajavad seevastu riigipoolset abi õppekirjanduse väljaandmise ja metoodikaalase täiendusõppe korraldamise näol. Samuti tunnevad nad puudust kolleegide ja lapsevanemate poolsest toetusest. Eesti keeles õpetavate pedagoogide kogemuste tõhusamaks vahetamiseks võiks näiteks luua interaktiivse veebikeskkonna, kus kogenud pedagoogid toetaksid nooremaid kolleege. Samuti võiks heaks lahenduseks olla eestikeelse õppe laiendamine põhikooli valikainete arvelt. Ühelt poolt tekitaks see vähem stressi kui kohustuslike ainete eesti keeles õppimine ja õpetamine, teiselt poolt annaks õpilastele eestikeelse õppe kogemuse ja võimaldaks õpetajatel arendada oma professionaalseid ning vajadusel ka keelelisi oskusi.

Reformi esimesed aastad on kindlasti katsetamise ja samas ka õigete lahenduste leidmise aeg. Tahaks loota, et esilekerkivad raskused leiavad õigeaegse lahenduse ning järgmistel aastatel muutub prioriteediks veelgi tõhusamate õppemeetodite väljatöötamine, mitte aga enam hoiakute ja keeleoskuse temaatika.

\section{Viidatud kirjandus}

Asser, Hiie 2001. Keelekeskkonna ja õppekava mõju vene kooli õpilaste eesti keele oskusele 1994-1999. - Kasvatus ja aated, 11, 7-16.

Asser, Hiie 2003a. Varajane osaline ja täielik keeleimmersioon eesti muukeelse hariduse mudelitena. Dissertationes pedagogicae Universitatis Tartuensis 3. Tartu: Tartu Ülikooli Kirjastus.

Asser, Hiie 2003b. Tendentsid ja tingimused muukeelse kooli arenguks Eestis. http://www. hm.ee/ (20.06.2006).

Asser, Hiie; Küppar, Maire; Kolk, Peeter 2005. Keelekümblusõpilaste õpitulemuste ja lapsevanemate hinnangute uuring. Uurimise aruanne. Õppeaasta 2004/05. Tartu. www. kke.ee (21.08.2006). 
Baker, Colin 2006. Foundations of Bilingual Education and Bilingualism. Fourth edition. Clevedon: Multilingual Matters Ltd.

Cummins, Jim; Swain, Merrill 1986. Bilingualism in Education: Aspects of Theory, Research and Practice. London, New York: Longman Group Limited.

EHIS = Eesti Hariduse Infosüsteem. Haridus- ja Teadusministeerium.

Hausenberg, Anu-Reet; Saarso, Kristi 2008. Eesti kirjanduse õpetamine eesti keeles. - Haridus, 9/10, 17-23.

Läänemets, Urve 2002. Multikultuursus ja muukeelse kooli üleminek kakskeelsele õppekavale. Tallinn: Jaan Tõnissoni Instituut.

Mehisto, Peeter; Marsh, David; Frigols, María Jesús 2008. Uncovering CLIL: Content and Language Integrated Learning in Bilingual and Multilingual Education. Oxford: Macmillan Publishers Limited.

Pavelson, Marje; Vihalemm, Triin 2002. The Russian child in the Estonian language school. - Marju Lauristin, Mati Heidmets (Eds.). The Challenge of the Russian Minority: Emerging Multicultural Democracy in Estonia. Tartu: Tartu University Press, 265-276

PGS 1993 = Põhikooli- ja gümnaasiumiseadus. Riigi Teataja, I 1993, 63, 892.

PGS 1997 = Põhikooli- ja gümnaasiumiseaduse $§ 52$ muutmise seadus. Riigi Teataja, I 1997, $69,1111$.

PGS 2000 = Põhikooli- ja gümnaasiumiseaduse $\S$-de 9 ja 52 muutmise seadus. Riigi Teataja, I $2000,33,195$.

Proos, Ivi 2005. Eestivenelaste keeleoskus ja suhtumine 2007. aasta gümnaasiumireformi. Uuringu "Integratsiooni monitooring 2005" aruanne. Tallinn: TLÜ Rahvusvaheliste ja Sotsiaaluuringute Instituut, 20-32. http://www.meis.ee/pictures/terve_aruanne. pdf (18.07.2007).

Rannut, Ülle 2001. Varase keelekümbluse ja eesti keele kui teise keele õppe teooria ja praktika. Magistritöö. Tallinn: Tallinna Ülikool.

Rannut, Ülle 2003. Muukeelsete õpilaste integreerimine eesti koolis. Õpik kõrgkoolile ning muukeelsete õpilastega töötavale aine- ja klassiõpetajale. Tallinn: Tallinna Pedagoogikaülikooli Kirjastus.

Rannut, Ülle 2005. Keelekeskkonna mõju vene õpilaste eesti keele omandamisele ja integratsioonile Eestis. Tallinn: Tallinna Ülikooli Kirjastus.

RÕK 2007 = Vabariigi Valitsuse määrus nr 235. Määruse nr 56 "Põhikooli ja gümnaasiumi riiklik õppekava” muutmine. Riigi Teataja, I 2007, 61, 392.

Skutnabb-Kangas, Tove; McCarty, Teresa 2008. Key concepts in bilingual education: Ideological, historical, epistemological, and empirical foundations. - Jim Cummins (Ed.). Encyclopedia of Language and Education. Volume 5: Bilingual Education. New York: Springer, $3^{-17}$.

TNS Emor 2004 = Eestikeelne aineõpe vene õppekeelega koolides: hetkeolukord ja vajadused. November-detsember 2004. TNS Emor. http://www.hm.ee/ (08.05.2005).

TNS Emor 2006 = Eestikeelne aineõpe vene õppekeelega koolides: hetkeolukord ja vajadused. November-detsember 2006. TNS Emor. http://www.hm.ee/ (11.07.2007).

Valk, Aune 1998. Mitte-eesti noorte psühholoogiline kohanemine mitmerahvuselises klassis: enesehinnang ja etniline identiteet. Tartu: Tartu Ülikool.

Vare, Silvi 1999. Eesti keele õpetamine vajab uuendamist. - Silvi Vare (koost., toim.). Keelekümblus kui integratsioonivõti. Projekti "Keelekümblus kui integratsiooni võti" väljaanne. Tallinn: Haridusministeerium, 45-56.

Vare, Silvi 2004. Eesti keel vene koolis. Haridus- ja Teadusministeerium. Eesti keelenõukogu. Tallinn: Eesti Keele Sihtasutus.

Vare, Silvi 2006. Vene koolide valmisolekust üleminekuks eesti õppekeelega gümnaasiumile 2007. aastal. - Eesti Rakenduslingvistika Ühingu aastaraamat, 2, 303-326. 
Vassiltšenko, Larissa; Pedastsaar, Tiia; Soll, Maie; Kala, Ulve; Kera, Silvia 1998. Venekeelse kooli erinevate mudelitega seotud ootused ja kartused haridussubjektide seas. M. Lauristin, S. Vare, T. Pedastsaar, M. Pavelson (toim.). Mitmekultuuriline Eesti: väljakutse haridusele. Projekti "Mitte-eesti noorte integratsioon Eesti ühiskonnas" väljaanne (VERA II). Tartu: Tartu Ülikooli Kirjastus, 149-186.

Natalia Vaiss (Jyväskylä Ülikool). Uurimisvaldkondadeks on eesti keele verbiaspekt ning kakskeelne haridus.

navaiss@jyu.fi 


\title{
ATTITUDES OF RUSSIAN-MEDIUM SCHOOL LEARNERS AND THEIR TEACHERS TOWARDS PARTIAL ESTONIAN LANGUAGE INSTRUCTION BEFORE IMPLEMENTATION OF THE EDUCATION REFORM IN 2007
}

\author{
Natalia Vaiss \\ University of Jyväskylä
}

This article is concerned with the development of bilingual education in Estonia. The extended use of CLIL (Content and Language Integration Learning) in the Estonian school system is related to a recently implemented education reform. According to this reform as of the 2007-2008 academic year, Russian-medium upper secondary schools began teaching one subject in Estonian. Furthermore, every forthcoming academic year, one additional subject is required to be added to the curriculum taught in Estonian until the official language instruction reaches a minimum limit of 60 per cent in the 2011-2012 academic year.

The present article is aimed at highlighting select findings of a study conducted around 4-9 months before implementation of the education reform. The research data was gathered with the help of online questionnaires. Participants included 30 CLIL teachers and 815 Russian-speaking ninth grade students. The sample represented not only students from different parts of Estonia but also CLIL and non-CLIL students.

This article focuses on exploring the attitudes of Russian-speaking ninth grade students and of Estonian CLIL teachers towards the education reform and studying in Estonian as a non-native language. Different aspects of student and teacher experience with CLIL are also analyzed, and both sides of CLIL - the positive and the negative - are shown from the respondents' perspective.

The results revealed that about a half of the ninth grade students participating were psychologically ready to study a few subjects in Estonian at upper secondary school. However, most of the respondents preferred to continue their studies at upper secondary school in Russian as the main language of instruction. Analysing the factors promoting the development of positive student attitudes towards learning in Estonian as a second language, some regional differences as well as some differences in the opinions of CLIL and non-CLIL students, in favour of CLIL students, were revealed. Some of the Estonian CLIL teachers were against the implementation of the obligatory education reform, mostly due to their previous experience with CLIL.

Keywords: bilingual education, education reform, second language acquisition, Estonian as a second language 